\title{
Rhopalura granosa sp. nov., an Orthonectid Parasite of a Lamellibranch Heteranomia squamula L., with a Note on its Swimming Behaviour.
}

By

D. Atkins, B.Sc.

With 4 Figures in the Text.

\section{Contents.}

Introduction

Description of Rhopalura granosa . . . . . . . . . . 234

The Plasmodia and their Distribution in the Host $\quad . \quad$. $\quad . \quad$. $\quad . \quad 239$

Number and Distribution of the Hosts Infected _. . . . . . . 244

The Swimming Behaviour of Rhopalura granosa $\quad . \quad$. $\quad . \quad$. $\quad . \quad$. $\quad .246$

SUMmary . . . . . . . . . . . . . . . . . . . 249

Appendix . . . . . . . . . . . . . . . . . . . . . . 249

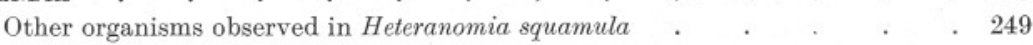

Literature

250

\section{INTRODUCTION.}

THE Orthonectida, a small group of rare parasites, have attracted considerable interest owing to their doubtful systematic position. In 1868 Keferstein (1868, pl. ii, fig. 8) figured, though he did not describe, a "problematic parasite" * from the digestive tube of Leptoplana tremellaris, but it was not until about 1877 that a serious investigation of these forms was undertaken by Giard (1877), who gave to the group the name of Orthonectida. Our knowledge of the organisation and lifehistory of these parasites, however, is in great part due to the admirable researches of Caullery and his collaborators. The Orthonectida are forms in which the sexual generation is formed asexually from germ cells produced in a parasitic plasmodium.

Some eight species of Rhopalura, and one of Stœcharthrum, are now known.

Rhopalura granosa sp. nov., parasitic in Heteranomia squamula L. (=Anomia aculeata Müller), in the Plymouth area, is the first Orthonectid

* This species was named Rhopalura (Intoshia) leptoplana by Giard (1880, p. 236) ; it was rediscovered and described by Jourdain (1880) - under the name of Prothelminthus hessi - at Saint-Vaast-la-Hougue, and by Caullery and Mesnil (1901 c, pp. 399-400) in the bay of Saint-Martin, under the old fort of Saint-Germain-des-Vaux. 
to be described from a Mollusc, members of the group being hitherto known from Annelids, Nemertines, a Planarian, and from an Ophiuroid, Amphiura squamata. The only previous record of an Orthonectid for the British Isles would seem to be that by McIntosh in 1873 (p. 129), when he described a curious parasite burrowing in the body wall of Lincus gessercnsis. The specific name granosa has been given on account of the presence of characteristic refringent bodies in the male (see p. 237).

\section{Description of RHOPALURA GRANOSA.}

In $R$. granosa the sexes are separate, and, as in other species of Rhopalura where the male is known, exhibit sexual dimorphism. Sexual dimorphism is so marked in the genus that Giard $(1879,1880)$ originally referred the two sexes in $R$. ophiocoma to two genera, Rhopalura and Intoshia.

\section{The Female.}

The female (Fig. 1, A and B) is cylindrical, tapering anteriorly and posteriorly, and about 190 to $210 \mu$ long, and 60 to $75 \mu$ broad, not including the cilia. Individuals, however, vary somewhat in shape, doubtless partly owing to their considerable powers of contraction; a narrow elongated female, ca. $230 \mu$ long and $55 \mu$ broad, is shown in Fig. 1, B, but this is an extreme form, and rarely seen.

Fig. 1, A and B, of $R$. granosa recall Julin's figures of "femelle aplatie" and "femelle cylindrique" of $R$. ophiocome (Julin, 1882, pl. ii, figs. 2 and 1). The type of female shown in Fig. 1, A, is not flattened, however, for there is no appreciable difference observable in the width as it rotates in swimming; the rings are no less clearly marked than in the elongated form (Fig. 1, B). Both forms are found among those issuing naturally from their hosts. Caullery and Mesnil (1901 c, pp. 395-397) think that possibly the cylindrical females of $R$. ophiocoma are a temporary state, leading to the flattened females: their specimens were apparently taken artificially from the host.

The body of the female $R$. granosa, which is entirely ciliated, shows eight rings, of which the first is the anterior, and the last the posterior terminal cone. The fourth and sixth rings seem to be formed of two rows of cells, while the second, third, fifth and seventh are formed of one row each. The anterior and posterior cones are formed of several rows. Between the rings there is a row of tiny cells, as in the male. The rings are superficial, involving the ectoderm only, the body not being segmented: they are more evident in some individuals than in others. When the animal is swimming forwards the cilia on the anterior cone are directed forwards, and those on the body posterior to it backwards (see Fig. 1, A). When the animal is swimming backwards, however, those on the second ring, as 

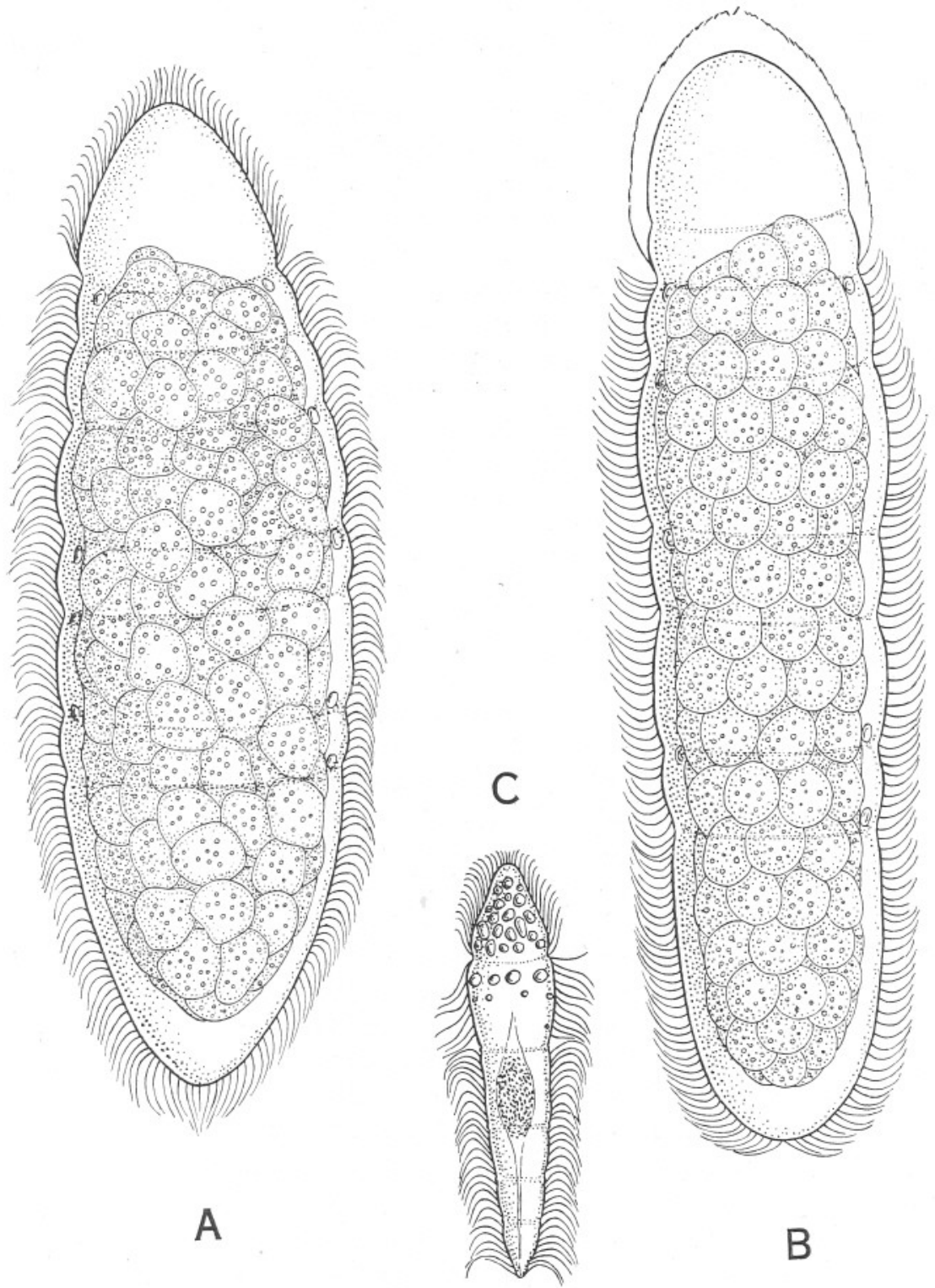

B

FIG. 1.-Rhopalura granosa. Sketches from life of individuals which had issued naturally from the host. The cilia are shown in profile only, although actually the animals are entirely ciliated: they are shown somewhat diagrammatically. $\times 573 \frac{1}{3}$.

A. Female. The cilia are shown as they appear during slow forward movement.

B. Rare, elongated form of the female. The cilia are shown as they appear during reversed swimming. In both forms the asymmetrical anterior extension of the mass of ova is due to the presence of the problematical organ, which is not shown in the figures.

c. Male. 
well as those on the anterior cone, become motionless and are applied closely to the surface of the body, the tips being directed anteriorly (see Fig. 1, B, and also p. 247).

The ectoderm cells of the anterior and posterior extremities are deeper than those covering the rest of the body, the depth of the anterior cells being especially noticeable. The latter, in particular, contain a number of granules towards their outer ends, which become red if a trace of neutral red is added to the water. In sections of animals preserved in Bouin's fixative and stained with Heidenhain's iron hæmatoxylin and acid fuchsin the ectoderm cells appear much vacuolated, the vacuolation occurring sometimes at the inner ends, and sometimes at the outer ends of the cells. A problematical organ is present in the anterior cone; narrow prolongations from the organ appear to encircle the cone. It has been suggested by Metschnikoff (1881, p. 285) that this structure may be a remnant of an alimentary canal, and by Caullery and Lavallée (1908 b, p. 465) a nervous ring. A few, one to four, large vacuoles are generally observable in the cells of the anterior cone.

A small number of refringent bodies occur at irregular intervals, in a. position between the rings of the body. These become orange with neutral red, and pale blue with methylene blue intra vitam staining.

The ova are numerous, very roughly about two hundred. They extend only slightly into the region of the anterior cone. They are about $14 \mu$ in diameter, with transparent cytoplasm containing a number of refringent granules, which become red with neutral red used intra vitam: it would appear to be these granules which in sections of material preserved in Bouin's fixative stain black with iron hæmatoxylin.

The embryos develop in the body of the parent: they are closely packed, and no movement of the ciliated larvæ is observable, such as occurs in R. pelseneeri (M. and C., 1905a, p. 429).

Embryos and ova have been observed, on several occasions, escaping from the parent in the region of the second and third rings. The fact that ova also have been seen to be expelled, points to the conclusion that these occurrences were not normal, but possibly due to unnatural conditions of observation ; the position of emergence may, therefore, also be abnormal. A genital pore, such as described by Caullery and Mesnil (1901 c, p. 394) for $R$. ophiocoma, could not be distinguished, at least in females sectioned while still within the host: no sections were made of those which had emerged.

\section{The Male.}

The male (Fig. 1, C) is cylindrical and slender, tapering anteriorly and posteriorly, the broadest region being the second ring. It is 87 to $95 \mu$ long and $20 \mu$ broad, not including the cilia. The body shows six super- 
ficial rings, of which the first is the anterior, and the last the posterior terminal cone. Between the rings is a row of tiny cells, the nuclei of which show clearly in sections. The anterior cone is formed of several rows of ectoderm cells, as is also the second ring.

A characteristic of the male is the presence of large irregular refringent bodies in the cells of the anterior cone, as well as in the first row of cells of the second ring. Occasionally smaller refringent bodies occur in other parts of the second ring. In R. ophiocoma, the only other species in which the males are known to have these curious large refringent bodies in the cells, they are present in the second ring only (Giard,

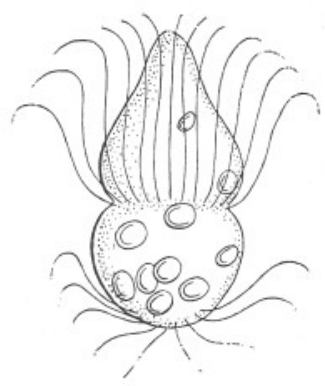

Fig. 2.-Rhopalura granosa. Ciliated larva, taken from the body of the parent. $\times 1470$.

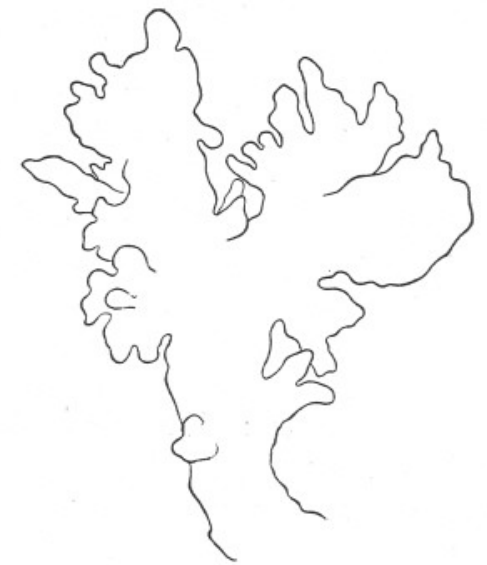

Fig. 3.-Rhopalura granosa. Fragment of a male producing plasmodium. $\times 70$.

1880 , p. 229 ; Julin, 1882 , p. 11). In sections of $R$. granosa preserved in Bouin's fixative these bodies frequently stain lightly with a dark periphery with iron hæmatoxylin and acid fuchsin, but others stain uniformly black. Caullery and Mesnil (1901 c, p. 393) found those of $R$. ophiocome disappeared in preparations treated with alcohol and xylol, a vacuole occupying their place. The fixative they used chiefly was a saturated solution of sublimate in sea-water, with the addition of $1 \%$ acetic acid.

The male of $R$. granosa is entirely ciliated. The cilia on the anterior cone are rather shorter and denser than those on the rest of the body; they are directed forwards as in the female. Those on the second ring are much less closely set than those on the posterior rings, but appear to be as long. In $R$. ophiocomar, the species which-of those so far described - seems most closely allied to $R$. granosa, the second ring is said to be unciliated, though Caullery and Mesnil (1901 c, p. 392 footnote) note that 
some isolated cells exceptionally bear long cilia. In sections the basal granules of the cilia stain very darkly and clearly with iron hæmatoxylin.

The "testis" is present about the middle of the body. The spermatozoa are flagellated.

\section{The Larva.}

The ciliated larva (Fig. 2) forced from the body of the female, by gentle pressure on the coverslip, is somewhat acorn-shaped,* being slightly constricted in the middle region, pointed anteriorly and broadly rounded posteriorly. (The pointed end is apparently anterior, as this is foremost when the larva swims.) It is about $19 \mu$ long. Ciliation is restricted to two bands of long cilia; one in the middle region about the slight constriction, and one posteriorly. Refringent bodies are present in both regions of the larva, but chiefly posteriorly. Cells could not be distinguished in the living state; larvæ were not sectioned.

The larva of $R$. granosa differs considerably in appearance from those so far described, namely, that of $R$. ophiocomce (C. and L., 1905, p. 266 ; 1908 b, p. 432, and pl. xv, figs. 43, 44) and $R$. pelseneeri (M. and C., 1905 a, p. 429 , and fig. 1), which appear to have no regular arrangement of the cilia, though Caullery and Lavallée (1908 b, p. 432), speaking of the very small size $(12-15 \mu$ in diameter) and great transparency of the former larva, say: "La disposition des cils mêmes est à peu près impossible à fixer; ils paraissent longs et peu denses. Ils donnent à ces larves un mouvement rapide, souvent tourbillonnant."

\section{Relationships.}

Caullery and Mesnil (1901 c, p. 419) have distinguished three groups in the genus Rhopalura, characterised as follows :-

Cilia limited to narrow rings, $R$. pterocirri St. J. (I).

Cilia entirely (or nearly)
covering the body. $\left\{\begin{aligned} \begin{array}{l}\text { Ova in compact } \\ \text { mass. }\end{array} & \left\{\begin{array}{l}R . \text { ophiocoma Gd. } \\ R \text {. intoshi Metchn. }\end{array}\right. \\ \text { row of ova. (III) } & \left\{\begin{array}{l}R . \text { leptoplance Gd. linear } \\ R . \text { pelseneeri C. and M. } \\ R . \text { linei Gd. } \\ R . \text { metchnikovi C. and M. } \\ R . \text { julini C. and M. }\end{array}\right.\end{aligned}\right.$

$R$. granosa evidently belongs to the second group. It is intermediate in size in both sexes, between $R$. intoshi from Lineus (Nemertes) lacteus and R. ophiocoma from Amphiura squamata. In the male it is clearly distinguishable from $R$. intosh $i$ by the presence of large refringent bodies, and from $R$. ophiocomce by having these bodies in the anterior cone, and the 
first row of cells of the second ring, while in $R$. ophiocoma they are restricted to the second ring.

The female of $R$. granosa has not been observed to be without cilia on the second ring, as occurs in certain individuals of $R$. ophiocomee (Giard, 1880, p. 232 ; Julin, 1882, p. 16 ; C. and M., 1901 c, p. 393) : it has eight rings, while that of $R$. intosh $i$ has nine (Metschnikoff, 1881, p. 284).

The larva differs from that of $R$. ophiocoma both in the shape and the arrangement of the cilia: the larva of $R$. intosh $i$ is unknown.

\section{The Plasmodia and their Distribution in the Host.}

In Heteranomia squamula the parasite is found replacing the gonad; it also occurs in the blood lacunæ and vessels in the mantle and the suspensory membranes of the gills, even extending into the dorsal ends of the gill filaments. In one host sectioned, numerous young plasmodia were present in the mantle margin in the posterior region. In heavy infections the parasitic plasmodia, containing the sexual forms of the Orthonectid, entirely replace the gonad of the host, rendering the determination of sex impossible. A fragment of a male containing plasmodium is shown in Fig. 3.

It would appear to be more usual for the males and females to occur in separate hosts, though it is by no means rare for them to be found together (see p. 244) ; when this occurs one sex generally predominates. Observations were mostly made on living Heteranomia, only two specimens being sectioned. One of the sectioned individuals was parasitised by plasmodia containing males only, many of them being nearly mature. It was well infected, plasmodia occurring in the mantle, visceral mass, suspensory membranes of the gills and dorsal ends of the gill filaments, but much of the gonad remained, sperm being recognisable among degenerating cells in some regions.

The second Heteranomia sectioned was very heavily infected, no gonad being recognisable. The great majority of the plasmodia in this host contained female Rhopalura, but in four separate regions of the visceral mass and mantle, males were present, many being nearly mature, and in at least two of these regions males and females occurred together in the same plasmodium (see Fig. 4). In one region (a), several branches or lobes of a plasmodium contained males, but in a very small portion only were the two sexes present together. In a second region (b), a small island of wellformed males, together with numerous germ cells and groups of germ cells, was present among females, and the males were not segregated in separate lobes of the plasmodium. In a third region (c), a few males were present in a small, almost empty plasmodial lobe, which was rather doubtfully traced into a female plasmodium. The fourth region (d), near 
the byssal muscle of the host, was by far the largest. This plasmodium appeared to contain males alone, though its considerable size made the tracing of its many branches difficult.

Where the males and females were present in the same plasmodium, the females yet appeared to contain unsegmented ova, so far as could be ascertained in the crowded condition of these. Caullery and Mesnil (1901 c, pp. 466-467) state that "dans des coupes d'une Amphiura, qui renfermait des plasmodes des deux sexes (of $R$. ophiocoma), plusieurs femelles, à l'intérieur desquelles, au lieu d'ovules, on trouvait des corps plurinucléés ayant tout à fait l'aspect des embryons décrits ci-dessus, mais un peu moins avancés. Nous les interprétons comme tels. Il est parfaitement admissible que, lorsque les deux sexes de Rhopalura existent dans une même Ophiure, les femelles adultes puissent, avant d'arriver au dehors, être fécondées et renfermer des embryons."

It is impossible to be entirely certain that the presence of males and females in the same plasmodium is not due to the disappearance of host tissue dividing two originally separate plasmodia, but it seems not improbable that a plasmodium may produce males and females at different times, the two phases overlapping to some extent. When plasmodia are well established in the host, they ramify greatly, and it is practically impossible to determine their number and limits. The presence of plasmodia with males only in the less heavily infected host sectioned would seem to indicate that, if it should prove to be correct that the two sexes are produced by the same plasmodium at different times, the male phase precedes the female.

It may be noted that curious thread- or rod-like bodies, or regions, of darker staining protoplasm were present in some small portions of female producing plasmodia. Among masses of these occurred a few normallooking groups of germ cells. The significance of these bodies is obscure : they may be a normal occurrence, or possibly parasites.

Caullery and Mesnil (1901 c, p. 384 ; C. and L., 1912, p. 159) have described plasmodia which produce one sex only, such as are usually found in R. ophiocomce from Amphiura squamata, as " unisexual," and those in which males and females develop side by side in the same plasmodium, as in R. metchnikovi from Spio martinensis (C. and M., 1901 c, pp. 384, 402), as "hermaphrodite." In $R$. intoshi from Lineus (Nemertes) lacteus an intermediate condition, between that of $R$. ophiocoma and $R$. metchnikovi, seems to obtain, "male," "female," and "hermaphrodite" plasmodia frequently occurring in the same host (Metschnikoff, 1881, p. 284).

Most known diœcious species of Rhopalura apparently have " hermaphrodite" plasmodia (R. leptoplance, C. and M., 1901 c, p. 399, and $R$. julini, C. and M., 1901 c, p. 412, in addition to those already mentioned), $R$. ophiocome being the only one with generally " unisexual " plasmodia. 
There appears, however, to be considerable variation in the condition of the plasmodia of this species in different localities. Giard (1880, p. 228) and Metschnikoff, 1881, p. 288) found that in R. ophiocom ce from Amphiura squamata from Wimereux, and from Naples and Spezzia respectively, a

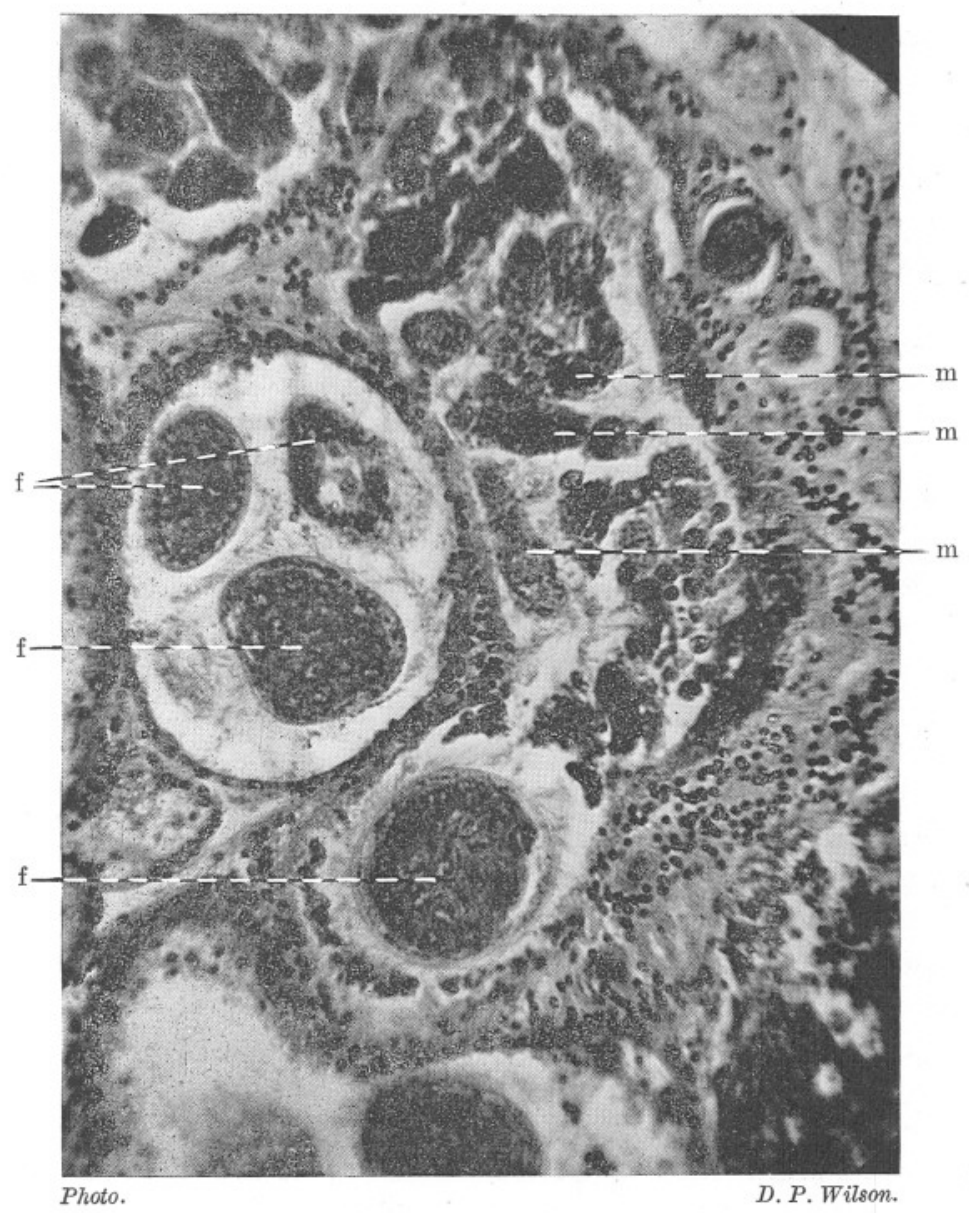

FIG. 4.-Rhopalura uranosa. Section of part of a plasmodium containing both males and females. F., female (transverse section); m., male (longitudinal section). Bouin's fixative: Heidenhain's iron hæmatoxylin and acid fuchsin. $\times$ ca. 1012 .

plasmodium produced Orthonectids of one sex only, males or females, though very occasionally the two sexes might be present in the same host. Julin (1882, p. 8), also working at Wimereux, says: "Je n'ai jamais rencontré dans le même hôte que l'une des deux formes, soit le mâle, soit la 
femelle, .. ." Caullery and Mesnil (1901 c, p. 392) found "Dans le cas de la $R h$. ophiocoma, chaque plasmode ne renferme que des individus d'un seul sexe, et souvent dans une même Ophiure, tous les plasmodes sont du même sexe," and in a foot-note add : "Dans l'anse Saint-Martin, un tiers environ des Ophiures parasitées renfermait uniquement des femelles, un tiers uniquement des mâles, un tiers à la fois des mâles et des femelles." On the other hand Koehler (1886, p. 609) working at Cette on the same species very frequently found males and females in the same Amphiura, the latter always being less numerous than the males. He rarely found one sex only; in some fifty infected Ophiuroids only two contained males alone. He not only found males and females in the same host, but in the same plasmodium. Working in the same months of the year as Julin, he says $(1886$, p. 610$)$ that the difference in their results can hardly be due to season, but that "Le genre de vie de ces remarquables parasites n'est donc pas le même à Cette qu'à Vimereux." In 1901 Caullery and Mesnil (p. 392) record that in an exceptional case they found adult males and females, together with developmental stages of both sexes, in the same plasmodium of $R$. ophiocoma, thus confirming Koehler's observation of 1886 .

In $R$. ophiocoma, where the host is parasitised generally by Orthonectids of a single sex (with the exception of Amphiura at Cette), Caullery and Lavallée (1912, p. 163, foot-note) believe that the infection has mostly arisen from a single larva, and that the rare instances where males and females are present in the same host, have arisen from multiple infection by larvæ of different sexes. They think that one larva may possibly give rise to several amœboid germs, which spread the infection in the host (1912, p. 153).

When mature the males and females leave the host. Those from the gonad of Heteranomia would seem to pass out by way of the renal ducts, for in sections free forms have been recognised in them. The renal ducts opening into the exhalent chamber, the parasite will pass out safely in the exhalent current of the host. The way of escape of those parasites present in the blood-vessels and spaces has not been observed.

The males and females apparently meet outside the host and fertilisation is effected. The mode of fertilisation was not observed in $R$. granosa. It has, however, been studied in $R$. ophiocome by Caullery and Lavallée (1908 b, pp. 428-430). They found that on mixing mature males and females artificially taken from the host, "Au bout de 10 à 15 minutes, on observe très fréquemment que des mâles sont remorqués, aux flancs des femelles, dans la moitié postérieure de celles-ci, comme s'ils s'étaient accidentellement pris dans le revêtement ciliaire et n'avaient pu s'en dégager. Une femelle remorque parfois deux mâles ; nous en avons même observé, une fois, trois. 
Ce phénomène, extrêmement commun dans les premiers temps du mélange, ne se retrouve plus ensuite. Nous avons pu nous convaincre que ces rencontres des mâles et des femelles étaient les circonstances mêmes de la fécondation. Et cependant, la façon dont nagent les deux catégories d'individus n'indique nullement qu'ils se recherchent. On voit les mâles passer très près des femelles sans a'y fixer. Il semble que ce soit purement le hasard qui produise les couples observés. Le contact des deux sexes n'est d'ailleurs jamais très long. Au bout de quelques minutes, les mâles se sont dégagés, les femelles sont de nouveau solitaires. Ce contact n'est jamais non plus intime. Le mâle paraît simplement retenu par sa ciliation à celle de la femelle.

. . nous avons constaté, d'une façon indiscutable, que les spermatozoïdes sont émis, à ce moment, au dehors. . . .

Caullery et Mesnil (1901, p. 394, pl. x, fig. 2, og.) ont signalé, sur la surface de la femelle, un pore, appelé par eux pore génital ; . . . Nous avons lieu de croire que c'est par là que les spermatozoïdes pénètrent."

The embryos develop while in the body of the parent, being liberated as ciliated larvæ. To Caullery and his collaborators is due the discovery that in the Orthonectida the ciliated larvæ carry infection to fresh hosts ; Caullery and Lavallée $(1910,1912)$ have caused experimental infection of Amphiura squamata by $R$. ophiocoma.

They (C. and L., 1912, p. 140) have discovered that in the life-history of the Orthonectida two generations alternate regularly :-

(1) a sexual generation, constituted in most species of males and females (some species, e.g. R.pelseneeri, are hermaphrodite) formed asexually from germ cells produced in the parasitic plasmodium.

(2) a generation produced from the fertilised ova of the preceding generation and carrying infection in the larval state to new hosts, where these larvæ are transformed into plasmodia, which give birth to the sexual generation.

It is puzzling to imagine how minute ciliated larvæ can effect safe settlement in a Lamellibranch. In the Anomiidæ the action of the lateral cilia on the gills is particularly furious, and the inhalent current rapid. One would not expect larvæ of not more than $19 \mu$ in length to be sufficiently strong swimmers to resist such a current, though it is possible that their cilia may interlock with those on the gills. If carried to the dorsal groove between the two demibranchs of each side they would in all probability eventually reach the mouth. It is possible, however, that after being thrown against the gills, they may be carried to the free edges of these, and then posteriorly in the rejection current, and dropped on the mantle margin in the posterior region. It may be noted that in one of the two Heteranomia sectioned, numerous young plasmodia were found in the 
mantle margin in this region, but the actual path of infection remains obscure.

If a number of Heteranomia from an infected batch be placed in a finger-bowl, numerous specimens of $R$. granosa may be obtained after a time. These will live quite happily in sea-water, whereas those obtained by opening the hosts, being not yet fully mature and ready for their free life, very quickly die. Even the cilia of immature forms frequently break down into droplets. It is remarkable that males, sufficiently mature for the sperm to be active, yet, when artificially liberated from the host die after a very few minutes in sea-water. In well-formed males obtained in this way sperm is frequently seen issuing from about the middle of the body (see also Julin, 1882, pp. 13-14), but this is almost certainly abnormal and not the true method of emission.

If a jet of air be passed through the bowl, the Heteranomia will live for weeks, and a supply of Rhopalura be available. A number of Heteranomia have been kept in this way for some fourteen weeks, though towards the end of that time specimens of Rhopalura were difficult to find, and females with segmented ova rare.

$R$. ophiocoma issues from Amphiura squamata chiefly in the late afternoon ; Caullery and Lavallée (1912, p. 143) suggest that the more or less fixed hour of emergence, providing for the simultaneous emission of the males and females, brings about the meeting of the sexes. No observations were made on the time of emergence of the Orthonectids from Heteranomia.

\section{Number and Distribution of the Hosts Infected.}

The infected Heteranomia, with one exception, have been obtained from masses of Lepralia foliacea. The Rhopalura was first found on November 25, 1932, infecting Heteranomia taken from a mass of Lepralia turned out of the Plymouth Aquarium, but which had most probably come from off Revelstoke Point or Stoke Point. Ten out of twenty-two (45.4\%) of the Lamellibranchs were found to be infected. Of these seven were infected with plasmodia containing females, and three with plasmodia containing males. In an unnoted number of Heteranomia infected with female forms, males were also present. This high percentage of infection, which has so far not been reached in material examined direct from the grounds, may possibly have been artificially induced by favourable conditions in the tanks.

On February 2, 1933, 149 Heteranomia from fragments of Lepralia dredged from off Revelstoke Point were examined. Of these twenty-four $(16 \cdot 1 \%)$ were found to be infected ; ten with males, ten with females (in one the plasmodia contained only immature forms, which from their size 
were probably female), and four with both males and females. When both sexes were present together the males were the more numerous, but as they are so much smaller than the females it does not necessarily follow that the plasmodia producing males occupied more space in the host than those producing females. The hosts varied from 3 to $10 \mathrm{~mm}$. in diameter : that of $3 \mathrm{~mm}$. was parasitised by male-bearing plasmodia.

The following animals, living either attached to, or sheltering in the crevices of the Lepralia obtained on February 2, were examined, but unsuccessfully, for the presence of Orthonectids : ten Chlamys distorta, ten Ophiothrix fragilis, five Ophiocomina nigra, and one Antedon bifida.

On February 6, 1933, 165 Heteranomia from fragments of Lepralia trawled from off Revelstoke and Stoke Points were examined. Of these only eleven $(6.6 \%)$ were infected ; four with males, five with females, and two with both males and females. In four the infection was slight. The hosts varied from about 6 to $12 \mathrm{~mm}$. in diameter.

On February 13, 1933, all the Heteranomia of any size from three large pieces of Lepralia trawled from off Stoke Point were examined. Of the ninety obtained fourteen $(15.5 \%)$ were infected; nine with males, two with females, and three with both males and females. Where the two sexes were present together the males were much more numerous than the females. The hosts varied from about 5 to $14 \mathrm{~mm}$. in diameter.

The Heteranomia obtained on February 2, 6, and 13 were opened and carefully examined at a magnification of about 140, so that it is unlikely that even small numbers of well-developed sexual forms would have been overlooked, though tiny plasmodia most probably would have been.

Thirty-eight Heteranomia from twenty-four Chlamys opercularis from the "Corner" Ground off the Mewstone were examined on January 20, 1933 : none were found to be infected.

An examination of seventy-three Heteranomia taken from the carapace of a single Maia squinado from the Mewstone Ground on March 20, 1933, showed only one to be infected, and that with plasmodia containing males alone.

It is possible that only those Heteranomia which occur in large communities, such as on masses of Lepralia, will be found to be generally infected. The branching colonies of the Polyzoan would also provide shelter from dispersing currents for the Orthonectids emerging from their hosts, thus facilitating the meeting of the males and females. Colonies of Lepralia foliacea were dredged and trawled chiefly off Revelstoke and Stoke Points at a depth of from 15 to 22 fathoms.

$R$. ophiocoma, a species on which most work has been done, has been found to infect $2.5 \%$ to under $10 \%$ of Amphiura squamata (Giard, 1880, p. 227 ; Julin, 1882, p. 9 ; Caullery and Lavallée, 1908 b, p. 425), varying widely in different parts of the same locality (Caullery and Mesnil, $1901 \mathrm{c}$, 
p. 391 ; Koehler, 1886, p. 609), and in different years (Metschnikoff, 1881, pp. 287, 288).

\section{The Swimming Behaviour of Rhopalura granosa.}

The Orthonectida were so named by Giard from their habit of swimming in a straight line. Giard states (1877, translated 1878, p. 182): "By the name of Orthonectida I have desired to recall their progression, which is so characteristic that it would of itself suffice for their recognition among the parasites with which they might be confounded.'

In $R$. granosa this habit would seem to be very generally confined to animals travelling relatively slowly, as they frequently do on being artificially liberated from the host. It was apparently on individuals of $R$. ophiocoma and $R$. linei obtained in this way that Giard made his observations. Observations on $R$. granosa have been made on individuals which had issued naturally from the hosts ; mostly on females because of their larger size. The males swim more rapidly than the females, for although there is little difference in the length of the cilia in the two sexes, the males are less than half the size of the females.

The females, when normally active, continually take short flights upwards, often touching the bottom of the watch-glass or finger-bowl only to leave it almost immediately : the males less frequently touch the bottom. They turn in all directions, this apparently being due to bending of the body. It is only when their activity becomes much reduced that they travel largely in contact with the substratum, and then nearly always in a straight line. When swimming at speed these Orthonectids mostly, though not invariably, follow a gently spiral path. They may, on occasion, swim almost perpendicularly upwards, and on reaching the surface film (in a watch-glass of water) swim beneath it for a short distance, before diving downwards again. It is particularly when an animal is swimming perpendicularly upwards that it may be observed to follow a spiral path, for the anterior end of the animal is seen to describe tiny circles. $R$. granosa is symmetrical, with apparently no longitudinal differentiation of cilia, but any slight bending of the body out of a straight line-such as might well occur in an animal capable of muscular contraction-would, owing to the rotation of the animal on its own axis, result in a spiral path being followed.

The cilia on the body do not beat directly backwards, but obliquely, and the animal moves forwards, rotating on its own axis to the left. This is actual, and not apparent rotation due to the appearance of metachronal waves. During backwards swimming the animal rotates to the right.

Caullery and Mesnil (1901c,p.402) noted that the males of R.metchnikovi while in the plasmodia " montrent une assez grande mobilité ; ils tournent sur leur grand axe à la façon d'une toupie." It is also of interest that they 
remark of the male, which is globular, measuring $40 \mu$ by $30 \mu$, with the anterior extremity larger than the posterior, "En raison sans doute de sa forme globuleuse, il n'a pas le mouvement en ligne droite, si général dans le groupe et que nous avons constaté, en particulier, pour la femelle. Il est extrêmement mobile et il décrit des sortes de cercles; il ressemble beaucoup à un Infusoire holotriche." It should be noted that Caullery and his collaborators - in common with previous investigators - in most of their work prior to that recorded in the 1912 paper, apparently used material obtained by opening the hosts.

As in other species of Rhopalura, there is in both sexes clear differentiation of the ciliation of the anterior cone from that of the rest of the body, in that when the animal is swimming forwards the cilia on the anterior cone appear to be directed forwards, while those on the rings posterior to it appear to be directed backwards (see Fig. 1, A). Over both regions, however, the effective beat is backwards, in spite of the difference in appearance. The appearance of the cilia on the anterior cone may be due to a restricted amplitude of beat; when an animal is swimming slowly and the beat can be seen, they then certainly appear to beat through a small angle. That the effective beat is backwards over the anterior cone may be observed by the movement of particles caused by the action of these cilia in animals artificially liberated before maturity from their host, and in consequence have lost the rest of the cilia while in sea-water (see p. 244). It is of interest that the cilia on the anterior cone resist disintegration considerably longer than those on the rest of the body, and may frequently be seen intact and active, when the others have been shed. These cilia beating alone appear unable to move the animal. It is possible that they have a sensory function in addition to a locomotory one; their differentiation from those on the rest of the body suggests this.

When the Orthonectids are swimming slowly forwards the appearance of the cilia is as shown in Fig. 1, A and C.

The cilia on the anterior cone, and in addition those on the second ringthough the latter during activity appear to be directed posteriorly with the cilia on the posterior rings - can be suddenly applied so closely to the surface that even at a magnification of 500 they appear as a thick, and but slightly striated cuticle (Fig. 1, B); during reversed swimming they were observed always to be motionless. In animals swimming forwards very slowly the cilia on the anterior cone have been observed, on occasions, to be motionless, but it is doubtful whether this occurs under normal conditions.

The cilia on the body posterior to the second ring rarely, if ever, become motionless, but the rate of beat may be much reduced temporarily so that the animal remains almost stationary. Females have been observed to remain for a time practically stationary, but with the body rotating. 
This is apparently due to change of direction of beat of the cilia. They have also been seen to stand on end and rotate, being evidently attached posteriorly owing to some viscid property of the cilia in that region.

From observations it seems that the direction of beat of the cilia may be changed, for the Orthonectids are capable of swimming forwards and backwards, though the forward movement is the more usual. Frequently, however, females artificially liberated from their host may continue swimming backwards for the few minutes they live. McIntosh (1873, p. 129), one of the first observers of an Orthonectid, noticed the backward swimming of the parasite he found in Lineus gesserensis.

The change in direction of movement from forward to backward swimming is abrupt, the animal giving a sudden dart backwards as the cilia on the anterior cone and second ring are closed down; during backward swimming these cilia have never been observed to beat, and would, therefore, seem to be incapable of reversing the direction of their beat.

In reversed swimming the cilia posterior to the second ring appear to be directed forwards (see Fig. 1, B) - that is in the opposite direction to that obtaining when the animals are swimming forward. Although it has been impossible to make observations on the movement of individual cilia, the change in direction of swimming would seem to be due to reversal of the effective beat of the cilia.

This power of sudden reversal of direction of movement is probably of value to the animal in rapid retreat from danger. On running into an obstacle, they have been observed frequently to swim in the reversed manner for a certain distance, then to turn round by muscular action, and continue the retreat in the same direction, but with the anterior end foremost. This reaction, however, does not invariably occur, for females at least appear to have a tendency to collect round debris, with the anterior end pushed against it, and the body cilia beating, though not at full speed. They frequently rub backwards and forwards against debris, at the same time contracting and expanding the body, and if the posterior extremity should come in contact, they have been observed to become caughtapparently by some viscid secretion or thread-and unable to free themselves, though the cilia, including those on the anterior cone, beat rapjdly. The production of this viscid thread may perhaps be abnormal, due to the unnatural conditions of observation; a female on one occasion was seen towing a male by such a thread, though at some considerable distance, and on other occasions females have been seen attached to each other posteriorly by a thread and tugging against each other, and so held stationary. It is just possible, however, that the viscid property of the cilia may play some part in the pairing of the males and females.

Males may frequently be observed continually reversing the direction of swimming, at very short intervals of time (a second or less). A 
characteristic movement of the male is that of sharply striking the water with the slender posterior region of the body: it is to this that the name Rhopalura refers (see Giard, 1880, p. 231).

I wish to thank the British Association for granting me the use of their table at Plymouth, and the Director and Council of the Marine Biological Association for facilities. For the microphotograph (Fig. 4) I am indebted to Mr. D. P. Wilson.

\section{SUMMARY.}

A new species of Orthonectid, Rhopalura granosa from Heteranomia squamula L., is described. The female is fusiform, and about 190 to $230 \mu$ long, and 55 to $75 \mu$ broad. The male is also fusiform, but less than half the size of the female, being only 87 to $95 \mu$ long and $20 \mu$ broad. $R$. granosa is distinguished from all other known species of Rhopalura by the presence in the male of large refringent bodies in the anterior cone, and in the first row of cells of the second ring. The male of $R$. ophiocome Giard, a species closely allied to $R$. granosa, has the refringent bodies in the cells of the second ring only.

The infected Heteranomia have been obtained from Lepralia foliacea trawled and dredged from off Revelstoke and Stoke Points. In Heteranomia examined direct from the grounds the infection in February, 1933 , varied from about $6 \cdot 6 \%$ to $16 \%$, but in a number taken from Lepralia from the Plymouth Aquarium in November, 1932, the percentage of infection was as high as $45 \cdot 4 \%$.

The parasite is found replacing the gonad of the host ; it also occurs in the blood lacunæ and vessels in the mantle, and in the suspensory mbranes of the gills, even extending into the dorsal ends of the filaments. In heavy infections the Orthonectid may entirely replace the gonad of the host.

Male and female containing plasmodia usually occur in separate hosts, but it is not uncommon for the two sexes to be found together. From sections it would seem that males and females may on occasion be produced in the same plasmodium.

The swimming behaviour of $R$. granosa is described.

\section{APPENDIX.}

\section{Other Organisms OBserved IN Heteranomia squamula.}

Few parasites and commensals, other than Rhopalura, were noticed in some four to five hundred Heteranomia examined. Those seen were :-

(1) Rounded masses, $c a$. 60 to $80 \mu$ in diameter, of tiny spores in the gonad of two individuals. 
(2) A Coccidian in the kidney. The number of Heteranomia infected with this parasite was not noted.

(3) A Rhabdocœle from each of six individuals of the seventy-three taken from the carapace of a single Maia (see p. 245). This Rhabdocœle almost certainly was not Graffilla gemellipara Linton, which is common in the mantle cavity and in the gut of Cardium edule from the Yealm Estuary and Millbrook. Although the specimens were large they did not contain viviparous young as is characteristic of $G$. gemellipara, and were more opaque than that species: they were broadly rounded anteriorly and pointed posteriorly. In addition to these six specimens another two or three have been seen at different times.

(4) A few larval Trematodes were seen in two or three Heteranomia taken from the Maia mentioned previously.

(5) In a number of Heteranomia a ciliate, possibly a species of Boveria, was present on the mantle.

\section{LITERATURE.}

Caullery, M. 1908. Titres et Travaux Scientifiques (1894-1908). Laval, 1908.

1914. Rhopalura pelseneeri C. et M., var. vermiculicola var. nov., Orthonectide parasite de Tetrastemma sermiculus Qtfg. Bull. Soc. Zool. France, T. xxxix, pp. 121-124.

Câllery, M., et Lavallée, A. 1905. Sur les larves ciliées produites par la femelle d'un Orthonectide (Rh. ophiocoma Giard). C.R. Soc. Biol., T. lix, pp. 265-266.

1908a. La fécondation et le développement des œufs chez un Orthonectide (Rhopalura ophiocoma). C.R. Acad. Sci., Paris, T. cxlvi, pp. 40-43.

1908b. La fécondation et le développement de l'œuf des Orthonectides. I-Rhopalura ophiocoma. Arch. Zool. Expér. et Gén., sér. 4, T. viii, pp. 421-469.

- 1910. Recherches expérimentales sur les phases initiales de l'infection d'une Ophiure (Amphiura squamata) par un Orthonectide (Rhopalura ophiocoma). C.R. Acad. Sci., Paris, T. cl, pp. 1781-1783.

1912. Recherches sur le cycle évolutif des Orthonectides. Les phases initiales dans l'infection expérimentale de l'Ophiure, Amphiura squamata, par Rhopalura ophiocoma. Bull. Sci. France et Belgique, Paris, T. xlvi (7), Vol. IV, pp. 139-171. 
Caullery, M., et Mesnil, F. 1899a. Sur trois Orthonectides nouveaux, parasites des Annélides, et l'hermaphrodisme de l'un d'eux (Stocharthrum giardi n.g., n.sp.). C.R. Acad. Sci., Paris, T. cxxviii, pp. 457459 .

1899b. Sur l'embryogénie des Orthonectides, et en particulier du Stochartrum giardi, Caull. et Mesn. Ibid., T. cxxviii, pp. 516-519.

1901a. Le cycle évolutif des Orthonectides. C.R. Soc. Biol., liii, pp. 524-527 ; and C.R. Acad. Sci., Paris, T. cxxxii, pp. 1232-1234.

_ 1901b. Sur la phase libre du cycle évolutif des Orthonectides. C.R. Soc. Biol., liii, pp. 859-860 ; and C.R. Acad., Paris, T. cxxxiii, pp. 592-593.

1901c. Recherches sur les Orthonectides. Arch. Anat. Micr., T. iv, pp. 381-470.

1904. Sur un organisme nouveau (Pelmatosphara polycirri n.g., n.sp.) parasite d'une Annélide (Polycirrus hamatodes Clap.) et voisin des Orthonectides. C.R. Soc. Biol., T. lvi, pp. 92-95.

GIARD, A. 1877. Sur les Orthonectida, classe nouvelle d'animaux parasites des Echinodermes et des Turbellariés. C.R. Acad. Sci., Paris, T. 1xxxv, p. 812-814. Translated in Ann. Nat. Hist., ser. 5, Vol. i, pp. 181-183, 1878.

1879. Sur l'organisation et la classification des Orthonectida. C.R. Acad. Sci., Paris, T. Ixxxix, pp. 545-547. Translated in Ann. Mag. Nat. Hist., ser. 5, Vol. iv, pp. 471-473, 1879.

1879. Les Orthonectida, classe nouvelle du phylum des Vermes. Journ. Anat. et Physiol., T. xv, pp. 449-464.

- 1880. The Orthonectida, a New Class of the Phylum of the Worms. Quart. Journ. Micro. Sci., Vol. xx (N.S.), pp. 225-240. An amended translation of his paper of 1879 .

Jourdarn, S. 1880. Sur une forme très-simple du groupe des Vers, le Prothelminthus Hessi S.J.=? Intoshia leptoplanæe A. Giard. Revue Sc. Natur., Montpellier, 2e sér., T. ii, pp. 68-74 (not seen personally).

Julin, C. 1882. Contribution à l'histoire des Mésozoaires. Recherches sur l'organisation et le développement embryonnaire des Orthonectides. Arch. Biol., T. iii, pp. 1-54.

Keferstein, W. 1868. Beiträge zur Anatomie und Entwickelungsgeschichte einiger See-Planarien von St. Malo. Abhandl. der k. Gesells. der Wiss. zu Göttingen, Bd. xiv (not seen personally).

Koenler, R. 1886. Contribution à l'histoire naturelle des Orthonectidés. C.R. Acad. Sci., Paris, T. ciii, pp. 609-610. 
Linton, E. 1910. On a New Rhabdocœle Commensal with Modiolus plicatulus. Journ. Exp. Zool., Vol. ix, pp. 371-385.

McIntosh, W. C. 1873. A Monograph of the British Annelids. Vol. i, Part I-The Nemerteans. Ray Society.

Mesnil, F., et Cauliery, M. 1905a. Sur le développement des ovules. et les larves ciliées d'un Orthonectide hermaphrodite (Rhopalura pelseneeri Caull. et Mesn.). C.R. Soc. Biol., T. lix, pp. 428-430.

1905b. Comparaison des cycles évolutifs des Orthonectides et des. Dicyémides. Ibid., T. lix, pp. 431-433.

1918. Notes biologiques sur les mares à Lithothamnion de la Hague. IV. Famille des Syllidiens. A. Groupes des Autolytés et des Exogonés, avec observation d'un Orthonectide parasite d'une Spharosyllis et d'un stolon sexué de Grubea. Bull. Soc. Zool. France, T. xliii, pp. 34-40.

Metschnikoff, E. 1879a. Zur Naturgeschichte der Orthonectiden. Zool. Anz., II, pp. 547-549.

— 1879b. Nachträgliche Bemerkungen über Orthonectiden. Ibid., II, pp. 618-620.

- 1881. Untersuchungen über Orthonectiden. Zeits. für wiss. Zool., Bd. XXXV, pp. 282-303.

St. Joseph, Le Baron De. 1896. Rhopalura pterocirri, n.sp., Orthonectidé parasite d'une Annélide. Bull. Soc. Zool. France, T. xxi, pp. 56-59. 